\title{
WEBSITE OPTIMISATION FOR SEARCH ENGINES - CONCEPT OF WEBSITE PROFILING
}

\author{
Karol KRÓL ${ }^{1}$, Dariusz ZDONEK ${ }^{2 *}$ \\ ${ }^{1}$ University of Agriculture in Kraków, Faculty of Environmental Engineering and Land Surveying; \\ k.krol@onet.com.pl, ORCID: 0000-0003-0534-8471 \\ ${ }^{2}$ Silesian University of Technology in Gliwice, Faculty of Organisation and Management; \\ dariusz.zdonek@polsl.pl, ORCID: 0000-0002-6190-9643 \\ * Correspondence author
}

Purpose: The article presents the concept of profiling a website. Profiling is focused on the quality of the SEO (search engine optimization) audit and the conclusions that flow from it, and its goal is to increase the effectiveness of the review. The primary purpose of the work was to assess the accuracy of the characteristics prepared in this way.

Design/methodology/approach: Four websites related to the hotel industry have been profiled and compiled in pairs, whose addresses were obtained from an Internet search engine. The tests were performed using selected testing tools.

Findings: It has been shown that based on an analysis of SEO attributes, one can create a technological profile of a site without browsing it first, and the relevance of profiling is determined by two factors: the auditor's experience and audit scope, including the quality and number of testing tools used.

Practical implications: The idea of profiling involves looking at a website only through the prism of an SEO audit, which changes the perspective and forces a more in-depth analysis of SEO tests. This can contribute to better use of information obtained during an inspection. Profiling is often treated as an activity supplementing an SEO audit in the case of a lack of access to testing tools when the test results are incomplete, insufficient, or inaccessible.

Originality/value: By analyzing SEO attributes, one can create a technology profile and a specific site characteristic without browsing it first. Two factors determine the relevance of profiling: the auditor's experience and the quality and scope of the audit performed by the testing application.

Keywords: SEO audit, optimization, profiling, website characteristics, Internet search engine. 


\section{Introduction}

It would not be possible to navigate Internet resources efficiently without search engines. It is estimated that they generate about $93 \%$ of global traffic on websites. The visibility of a site in search results increases its effectiveness. Pages placed on the first Search Engine Result Page (SERP) record an increase in conversion by an average of $14.6 \%$ and are perceived as credible and of better quality (Dwornik, 2017; Król, and Zdonek, 2017b). Statistics confirm this $79 \%$ of search engine users only view the first page of search results (Beitzel et al., 2007). The role of search engines in the distribution of content is, therefore, crucial and can determine the success of a site.

Websites are created for a specific purpose. Their effectiveness is conditioned by the degree of their implementation, which in Internet marketing is referred to as the goal conversion (Król, 2017a). The achievement of goals fits in with the essential functions that the websites perform - information, marketing, booking, or paying (Król, 2015). Websites will not fulfill their tasks if they are not visible on the Internet. The visibility of a site depends on many factors and can be considered on many levels, but most often, it is identified with clarity in the search results. Relation to the so-called "Findability," which determines the level of "readiness" of a site for location through search engines (Morville, 2005). The success of entities that use websites in their operations can, therefore, be conditioned, to a large extent, by their optimization. As a consequence, the budgets for optimization activities and search engine marketing are growing faster in Poland than the spending on other types of online advertising (Ocetkiewicz, 2017).

\section{Website optimization for search engines}

Search Engines Optimisation (SEO) for websites is aimed at achieving and maintaining a website's best visibility in the results of organic search engines for selected keywords (Połóg et al., 2015). The optimization allows for the triggering of a website's marketing potential (Król, 2018) and is related to the improvement of its broadly understood quality - in today's world, SEO is ruled by quality (Woźniak, 2015, p. 27). Website optimization has an indirect impact on the competitiveness of a company and its recognition on the market, broadening the range and effectiveness of the presentation of the offer on the web. The goal of optimization is to get as many clients as possible from organic search results (Duda, 2018) by introducing elements that will help the algorithm assign the page to the appropriate key phrases - thanks to giving the search engine a clear message, which is important on a website, it knows what queries should be shown on this page (Żytko, 2015, p. 18). SEO mainly aims to adapt the code, 
environment, structure, and content of a website to the search engine algorithm (Słowik, and Socha, 2016). Website optimization brings long-term and lasting benefits in a more natural way than positioning, which is a form of competition for a maximum display of a site in search results (Gałecki et al., 2016).

Website optimization is growing in popularity (Gaczkowski, 2011). In the United States alone, the increase in expenditure on SEO is forecasted to be almost 80 billion USD in 2020 (Ocetkiewicz, 2017, p. 11). In Poland, 2016 ended with expenses on SEO at a level of 1, 170 million PLN, and the SEO and SEM market (at the end of 2017) reached a value of 1,350 million PLN (Ocetkiewicz, 2017, p. 13).

Optimization of websites for search engines is undertaken in two dimensions - directly on the website (on-site SEO) and off-site (off-site SEO). On-site SEO focuses on identifying and improving those attributes of the site that may affect its worse placement in the search results, where - on-site optimization is simply creating a good site. Useful and helpful for both the recipient and the search engines (Żytko, 2015, p. 25). On-site optimisation aims to promote as many keywords as possible, which will increase the number of users (clients) obtained from natural search results - proper definition of keywords is the foundation of SEO activities (Smaga, 2011, p. 16). In Poland, websites are most often optimized for Google search, which is the most popular among users (StatCounter, 2018).

On-site optimization covers both the technical aspects of the website's functioning, e.g., responsiveness, performance, and code structure, as well as published content. There is a need to prepare unique and extensive content, as well as its well-thought-out distribution (Grzybowska, 2017; Król, and Zdonek, 2017a). The test results confirm this. 82\% of Internet users admit that the usefulness of content affects the positive perception of the subject that makes it available (Ałaszkiewicz, 2015). Also, user-generated content is becoming increasingly important. Research has shown that the appearance of a single review on a product website may increase the conversion rate by up to several dozen percent (Chabior, 2017).

These few reasons should offer some clarity, regardless of the industry or business size, as to why businesses need SEO to take their brand to the next level: 1) organic search is most often the primary source of website traffic; 2) SEO impacts the buying cycle; 3) SEO builds trust and credibility; 4) SEO is relatively cheap; 5) SEO brings new opportunities to light.

\subsection{SEO audit}

The concept of SEO audit is related to the optimization of websites for search engines. Its task is to indicate sensitive points of the website where optimization may affect the visibility in search results (Suchy, 2017).

There is no one commonly accepted pattern of SEO audit (Słowik, and Socha, 2016). Usually, it is characterized by extensive expert service, the nature of which depends on the auditor's skills and experience. Generally, they decide about the scope of the audit and the form of the final report. The SEO audit is performed using various applications that automate tests 
(Internet, desktop, browser plugin). The results of individual examinations are presented with the help of point scores (so-called SEO Score), letters, or graphics. The details of the audit are included in the final report, which should also include a list of post-audit recommendations (Sztal, 2014).

\subsection{The essence of site profiling}

In general, profiling is a process of determining the characteristics of an individual facility or entity based on available data. It is based on inference resulting from observations, simulations, and experiments. It is commonly associated with forensics (see Konieczny, and Szostak, 2011), although the principles of criminal profiling can also be applied in other areas of life.

The essence of profiling a website is to create a site's characteristics only based on the results of an SEO audit, and it aims to increase the effectiveness of the inspection (Figure 1). In profiling, it is not advisable or even forbidden to browse a site earlier. The idea of profiling involves looking at a website only through the prism of an SEO audit, which changes the perspective and forces a more in-depth analysis of SEO tests. This can contribute to better use of the information obtained during an inspection.

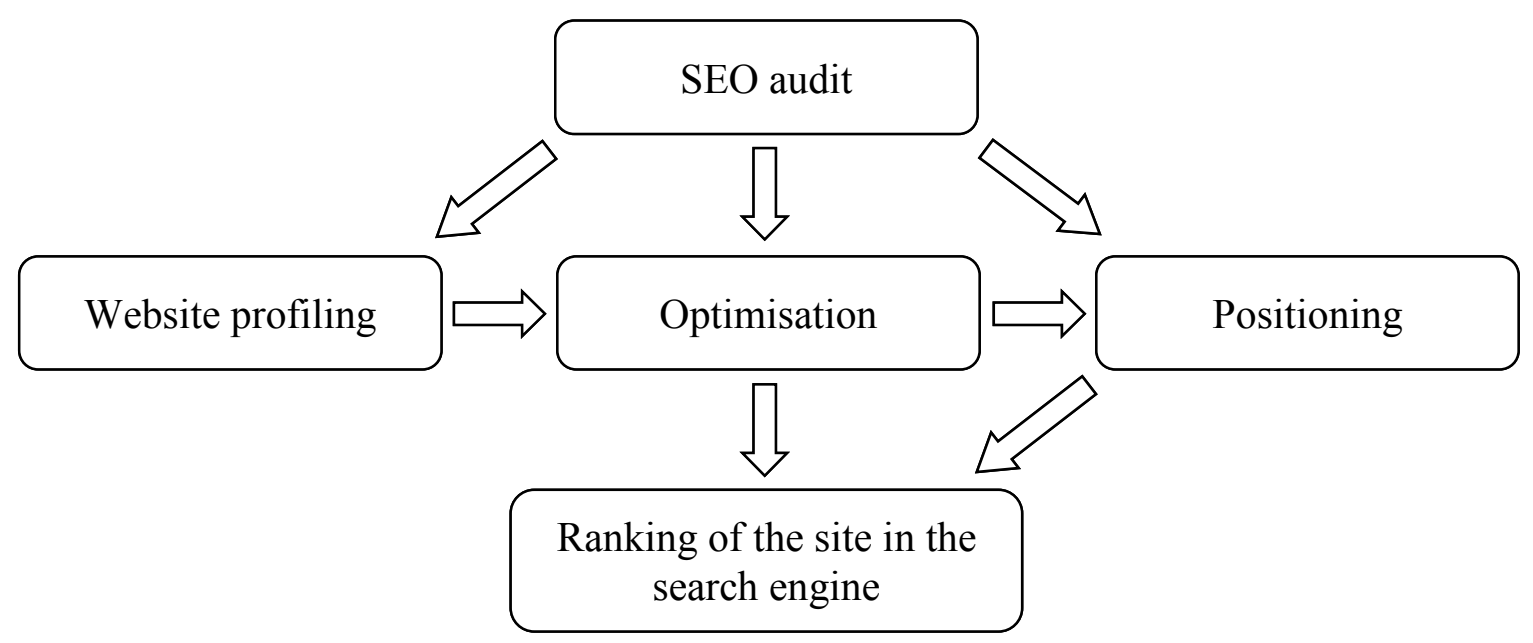

Figure 1. Profiling of a site concerning optimization and positioning. Source: own study.

The auditor in the process of profiling a website uses various testing tools and knowledge in the field of design techniques, including programming, graphic design, ergonomics, and usability, as well as cognitive psychology, covering issues related to the perception of Internet-specific messages. It is also necessary to learn about off-site matters, including the knowledge of operating principles of browsers, the construction of search engine rankings, and the authority of the website (domain). The ultimate goal of the auditor is to link the parts of the assessment to a specific type of site or a particular feature.

The starting base for profiling a website is the results of SEO tests, which allow the use of generalizations, e.g., scientific, methodological or those resulting from the auditor's experience, e.g., if the site is responsive, it is probably based on the Content Management System (CMS) 
and many components, and also features its dynamic content presentation and interactivity. The disadvantage of generalization is that it is not unique (a responsive site can be managed using an FTP client). They, therefore, do not give absolute certainty and are fraught with the error of petitio principii.

Profiling is often treated as an activity supplementing an SEO audit in the case of a lack of access to testing tools when the test results are incomplete, insufficient, or inaccessible. The outcome of profiling is the characteristics of the site (in situ assessment, status), which is verified with the actual state in the process of direct browsing the site (during inspection tests). A list of sensitive attributes requiring improvement and a list of post-control recommendations are usually prepared after profile verification.

\section{The legitimacy and purpose of the research}

The goal of optimization is to better place one's site in the search results by improving its broadly understood quality, as well as increasing its availability for selected keywords. This translates into website usage statistics, including an increase in the number of unique visits and an increase in the time users spend on the site. The optimization would not be possible without an SEO audit. The effectiveness of the inspection can be increased by using site profiling. This excludes its previous browsing, which means it is not burdened with acquired prejudices and opinions, and it assumes a higher concentration of the auditor on the quality and results of the audit, as well as on the conclusions that flow from it.

The work aimed to analyze the relevance of website profiles created only based on the result of an SEO audit, verification of the similarity between sites that obtained a similar or identical result in the SEO audit, and evaluation of the effectiveness of testing tools. At the same time, research questions were posed: is it possible to create a site's technology profile from an analysis of SEO attributes without browsing it first? What determines the accuracy of profiling? Does an identical SEO audit point score entitle generalization? Do sites with equal an SEO Score have similar attributes?

\subsection{Materials and methods}

Four websites related to the hotel industry have been profiled and compiled in pairs, whose addresses were obtained from an Internet search engine. Their selection was intentional and depended on the result obtained in the SEO reference audit. The reference audit was carried out using the "SEO Audit" Internet application (pozycjonowanie.pl, further S1). It aimed to obtain a synthetic SEO Score final, which reflected the degree of search engine optimization (at the time of the test and according to the testing algorithm). Sites that obtained 1 point in the reference audit were paired (out of 5 possible to get), and those that got 4 points were treated 
as reference (reference sites). The SEO audit constituting the basis for profiling was carried out using four tools (Table 1).

Table 1.

Tools used in assessing the degree of website optimization for search engines

\begin{tabular}{|l|c|c|c|}
\hline $\begin{array}{l}\text { Testing application } \\
\text { (Internet address) }\end{array}$ & Name & Name of SEO point note & Scale of measurement \\
\hline $\begin{array}{l}\text { SEO audit } \\
\text { (pozycjonowanie.pl) }\end{array}$ & S1 & SEO Score & $0-5$ \\
\hline $\begin{array}{l}\text { SEO Tester Online } \\
\text { (seotesteronline.com) }\end{array}$ & S2 & Final Score & $0-100$ \\
\hline $\begin{array}{l}\text { Zadroweb SEO Auditor } \\
\text { (zadroweb.com) }\end{array}$ & S3 & SCORE & $0-100$ \\
\hline $\begin{array}{l}\text { SEO Analyzer } \\
\text { (neilpatel.com) }\end{array}$ & S4 & SEO Score & $0-100$ \\
\hline
\end{tabular}

The applications were selected due to the lack of usage limits, including no license fees or a restriction of tests, as well as due to the varied scope of tests and various scales of assessment. The audit was carried out without becoming familiar with the tested websites. At a later stage, the results were analyzed and confronted with the actual state during inspection tests. This allowed us to assess the accuracy of profiling.

\subsection{Profiling results - synthesis}

Sites that obtained 1 point in the reference audit were characterized by an insufficient number (or lack thereof) of referring domains and a small number of backlinks. Critical errors (requiring immediate improvement) were noted in their assessment. Also, these sites were characterized by a low or zero value of authority indicators, including Page Authority, Domain Authority, MozRank and MozTrust, Trust Flow, and Citation Flow.

The initial profile of each site was prepared based on the result of an SEO reference audit performed using the S1 application. It allowed us to create both the characteristics of websites and the testing application itself. The website 1 obtained a score of 1 out of 5 possible points in the S1 test. Analysis of the site presentation in the form of a screenshot - "trapezoidal 3D" did not provide a definite answer as to whether it is adapted to portable devices or not. Analysis of the audit results showed the resources included in the "wp-content" folder, which is characteristic for sites created on the basis of WordPress CMS, and large graphic files that significantly increased the importance of the website. This influenced the assessment of its performance, which was awarded a score of $0 / 100$ points in the audit. In the manner of profiling, it was found that the site was created based on CMS and had an insufficient performance. There was no unambiguous opinion regarding the responsiveness and character of the website (static or dynamic). 
In the case of the WWW2 website (1/5 mark in the reference test), there was no advanced functionality (no components) and no social signals. There was also a lack of data on the authority of the site, no incoming links, no visitor statistics, and no activity on social media. Also, the audit showed code syntax errors. A performance indicator of $67 / 100$, the page loading time of 2.72 seconds, and a relatively small file size of $1.80 \mathrm{MB}$ (compared to other sites) indicated that it could be a static site (Table 2). During testing, the DNS Wildcard service was also identified, which may negatively affect the placement of the site in the search results. In the manner of profiling, there was no CMS content management system, no responsiveness, code syntax errors, and the static nature of the site.

Table 2.

Measurement values of selected website attributes by testing applications

\begin{tabular}{|c|c|c|c|c|c|c|c|c|}
\hline Website & \multicolumn{4}{|c|}{ WWW1 } & \multicolumn{4}{|c|}{ WWW2 } \\
\hline Testing application & S1 & $\mathrm{S} 2$ & S3 & S4 & S1 & S2 & S3 & S4 \\
\hline Performance $(0-100)$ & 0 & 0 & 0 & 82 & 67 & 67 & 67 & 78 \\
\hline Site loading time (s) & 12.74 & $\mathrm{~b} / \mathrm{d}$ & 4.09 & 4.05 & 2.72 & $\mathrm{~b} / \mathrm{d}$ & 0.89 & 0.44 \\
\hline Site size $(\mathrm{MB})$ & 10.66 & $\mathrm{~b} / \mathrm{d}$ & $\mathrm{b} / \mathrm{d}$ & 0.752 & 1.80 & $\mathrm{~b} / \mathrm{d}$ & $\mathrm{b} / \mathrm{d}$ & 0.3 \\
\hline Critical errors & 1 & $\mathrm{~b} / \mathrm{d}$ & 0 & 0 & 6 & $\mathrm{~b} / \mathrm{d}$ & 3 & 2 \\
\hline Warnings & 6 & $\mathrm{~b} / \mathrm{d}$ & 5 & 0 & 7 & $\mathrm{~b} / \mathrm{d}$ & 9 & 2 \\
\hline Correct & 17 & $\mathrm{~b} / \mathrm{d}$ & 11 & 19 & 11 & $\mathrm{~b} / \mathrm{d}$ & 4 & 15 \\
\hline Responsiveness & 0 & $\mathrm{~b} / \mathrm{d}$ & $\mathrm{b} / \mathrm{d}$ & 1 & 0 & $\mathrm{~b} / \mathrm{d}$ & $\mathrm{b} / \mathrm{d}$ & 0 \\
\hline Website & \multicolumn{4}{|c|}{ WWW3 } & \multicolumn{4}{|c|}{ WWW4 } \\
\hline Testing application & S1 & $\mathrm{S} 2$ & S3 & S4 & S1 & $\mathrm{S} 2$ & S3 & S4 \\
\hline Performance $(0-100)$ & 64 & 64 & 64 & 64 & 67 & 67 & 67 & 68 \\
\hline Site loading time (s) & 6.93 & $\mathrm{~b} / \mathrm{d}$ & 2.47 & 2.02 & 2.81 & $\mathrm{~b} / \mathrm{d}$ & 1.29 & 1.36 \\
\hline Site size (MB) & 4.65 & $\mathrm{~b} / \mathrm{d}$ & $\mathrm{b} / \mathrm{d}$ & 1.7 & 1.25 & $\mathrm{~b} / \mathrm{d}$ & $\mathrm{b} / \mathrm{d}$ & 0.715 \\
\hline Critical errors & 0 & $\mathrm{~b} / \mathrm{d}$ & 2 & 0 & 0 & $\mathrm{~b} / \mathrm{d}$ & 0 & 0 \\
\hline Warnings & 7 & $\mathrm{~b} / \mathrm{d}$ & 4 & 3 & 3 & $\mathrm{~b} / \mathrm{d}$ & 7 & 0 \\
\hline Correct & 17 & $\mathrm{~b} / \mathrm{d}$ & 10 & 16 & 20 & $\mathrm{~b} / \mathrm{d}$ & 9 & 19 \\
\hline Responsiveness & 1 & $\mathrm{~b} / \mathrm{d}$ & $\mathrm{b} / \mathrm{d}$ & 1 & 0 & $\mathrm{~b} / \mathrm{d}$ & $\mathrm{b} / \mathrm{d}$ & 0 \\
\hline
\end{tabular}

S1 -WWW audit (pozycjonowanie.pl/audyt-seo),

S2 - SEO Tester Online (seotesteronline.com),

S3 - SEO Auditor ZadroWeb (zadroweb.com/seo-auditor),

S4 - SEO Analyzer (neilpatel.com/seo-analyzer).

In the case of the WWW3 website (4/5 mark in the reference test), responsiveness, the WordPress CMS content management system, optimized graphic files, and relatively large JavaScript script files (2.48 MB), which may need to be optimized, were noted. On the other hand, in the case of the WWW4 website (4/5 mark), the jQuery library was used to create it, which may indicate that the site presents dynamic objects, such as a rotator or carousel of images. Analysis of the other attributes of the site indirectly showed that it is not adapted to mobile devices. In comparison to the others, the site was distinguished by many linking domains and a lack of so-called critical errors. 


\subsection{Observations and conclusions}

The initial profile of a website should be prepared based on one previously selected application, as well as authorized and aggregating tests on various planes. It is then recommended to verify the profile based on the results of tests carried out with the help of additional applications. In the first place, the tests should be subject to the critical attributes of the site, including responsiveness (Rempel, and Bridges, 2013), performance (Bocchi, De Cicco, and Rossi, 2016) and usefulness and uniqueness of content (Holliman, and Rowley, 2014), although in the described case, no content attribute was verified.

Each of the testing applications assigns the website the final SEO Score, which is a summary of the SEO audit. The last notes obtained with the help of selected applications are, however, different. The website1, which in the reference S1 test received a score of $1 / 5$, in tests performed with the help of other applications, obtained a result similar to or better than the reference sites, i.e., those that received a $4 / 5$ mark in the S1 test (Table 3). This means that the final result estimation takes place in each testing application based on various criteria. The range of tests and the manner of measuring the same attributes of the site are also different. This makes profiling difficult and confirms that its accuracy depends on the quality of the testing application, which should be authorized (e.g., by an entity of recognized global reputation), and the number of carried out tests (number of used testing applications). In profiling, a set of applications that aggregate tests that are complementary to one another can be useful. This allows one to test a website better and verify the measurement values of the same website attributes.

Table 3.

The values of synthetic SEO final scores obtained with the help of testing applications

\begin{tabular}{|c|c|c|c|c|c|c|c|c|}
\hline Website & \multicolumn{4}{|c|}{ WWW1 } & \multicolumn{4}{c|}{ WWW2 } \\
\hline Testing application & $\mathrm{S} 1$ & $\mathrm{~S} 2$ & $\mathrm{~S} 3$ & $\mathrm{~S} 4$ & $\mathrm{~S} 1$ & $\mathrm{~S} 2$ & $\mathrm{~S} 3$ & $\mathrm{~S} 4$ \\
\hline SEO Score & $1 / 5$ & 50 & 62.62 & 43 & $1 / 5$ & 27.3 & 49.53 & 36 \\
\hline Website & \multicolumn{6}{|c|}{ WWW3 } & \multicolumn{5}{|c|}{ WWW4 } \\
\hline Testing application & $\mathrm{S} 1$ & $\mathrm{~S} 2$ & $\mathrm{~S} 3$ & $\mathrm{~S} 4$ & $\mathrm{~S} 1$ & $\mathrm{~S} 2$ & $\mathrm{~S} 3$ & $\mathrm{~S} 4$ \\
\hline SEO Score & $4 / 5$ & 54 & 71.03 & 37 & $4 / 5$ & 44.1 & 71.96 & 39 \\
\hline
\end{tabular}

S1 - WWW audit (pozycjonowanie.pl/audyt-seo),

S2 - SEO Online Tester (seotesteronline.com),

S3 - SEO Auditor ZadroWeb (zadroweb.com/seo-auditor),

S4 - SEO Analyzer (neilpatel.com/seo-analyzer).

Source: own study.

The measurements of the time of loading a website in a web browser window made using the S1 application are much larger than those obtained with the other testing applications. Still, the S3 application does not carry out such measurement at all. It is difficult to indicate the reason for this discrepancy (the time of loading a site in a browser window can be measured in different variants and circumstances). The results of performance measurement are also puzzling. The measurement made using the application S1, S2 and S3 showed that the WWW1 site requires performance optimization, which results from the relatively large graphic files used 
to create it (during the audit, it was possible to compress image files by as much as $7.7 \mathrm{MB}$, i.e., by $76 \%$ ). At the same time, measuring the performance of this site in the test mode with the S4 application was the best among all. So how was the measurement carried out, and what was measured? Research leads to the conclusion that in various testing applications. However, the name of the measured attribute is the same, the measurement method is different, and thus various de facto attributes of the site are measured. This makes profiling difficult and justifies cross-checks.

The applications used in the SEO audit perform general tests, covering basic website attributes, and requiring interpretation. The verification of responsiveness, which is not carried out at all by the S2 and S3 applications, leaves much to be desired. In the S1 application, the results are not very legible, which makes it ambiguous. This is similar in terms of monitoring activity in social media. Limited (general) measurement of social media signals is carried out only in the case of the S1 and S2 applications. The S3 application verifies only the output links to social networks. The scope of tests performed by applications made available free of charge is therefore limited, and what is important to note is that this is a deliberate procedure.

\subsection{Roles performed by free auditing applications}

The relatively narrow scope of tests and their lowly specialized (general) nature allows one to conclude that free audit applications, in addition to their essential function, also fulfill specific tasks for their creators. They are usually an element of the so-called diagnostic and information infrastructure. The services provided here are a means to an end, although their quality is usually high. The auditing services perform several essential functions, including (1) playing the role of the "surrounding" of the core ("main") sites, "focus traffic", i.e., they acquire, "catch" traffic on the network, acting as a kind of "scraping funnel"; (2) obtaining data about users, e.g., full audit results in the form of PDF are available after providing an email address, or use of the application is possible after creating (registering) a user account; (3) leaving cookies on recipients' devices, which can then be used in remarketing; (4) playing information, education, presentation and, finally, advertising roles.

The main task of free testing applications is to present the main assumptions of the SEO audit and to enable it to be carried out by itself, but to a limited extent, with an indication that a full audit is performed for a fee. At this stage, a test application and synthetic SEO Score points are displayed that reflect the quality of the site in each test plane. Audits made available free of charge are there to arouse interest and a willingness to order a paid service, which is usually presented as comprehensive and guaranteeing the efficiency of the website. In the presentation of paid services, the auditor is presented, introduced as the client's supervisor and advisor, as well as the coordinator of corrective actions (Figure 2). 


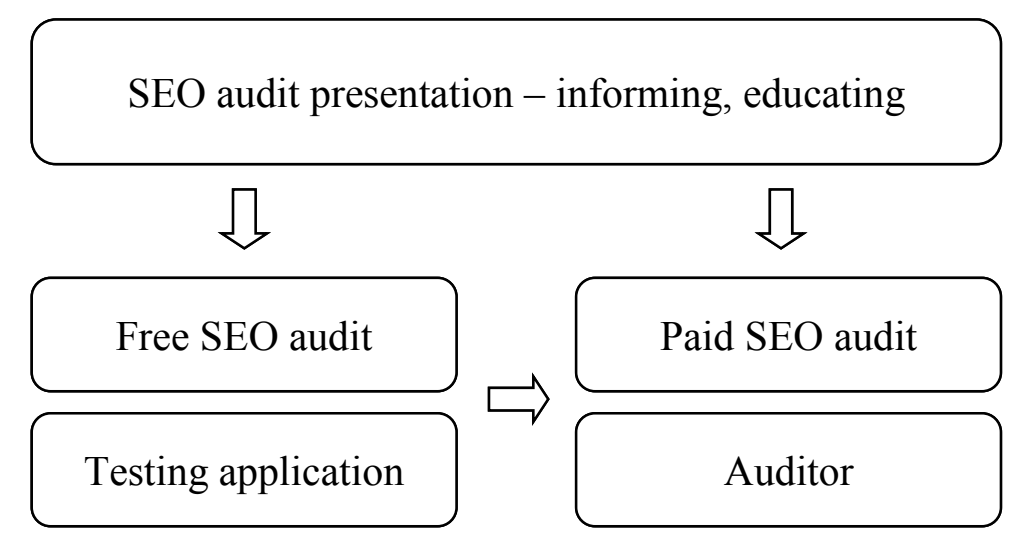

Figure 2. Diagram of dissemination of information about the SEO audit and sharing testing tools to persuade one to buy a paid service. Source: own study.

\section{Summary}

Profiling is accompanied by a risk of drawing incorrect conclusions from the audit results if one application is used to carry out an audit. While browsing the websites, in the process of verification of profiling results, it was found that the WWW1 site is responsive. A diagnosis made only based on the responsiveness analysis made with the $\mathrm{S} 1$ application turned out to be wrong.

The same website can get different final scores (SEO Score) in audits made using various testing applications. This justifies testing a site with at least two tools. The use of many testing applications (acquiring data about the website) significantly enhances profiling and increases the accuracy of the characteristics created in this way. At this point, it is worth emphasizing that a website optimized and created in compliance with project standards, will always achieve a high score in the SEO audit, regardless of the type of testing application.

If, in the evaluation of the website, many testing applications were used, and several end scores were obtained (with different spans), it may be helpful to standardize these using singleunit methods. The accumulation of many synthetic scores acquired for an optimized site will not significantly reduce its final assessment. At the same time, the same accumulation of partial notifications obtained for websites requiring optimization may slightly overstate the synthetic result of the assessment.

The same point score of the SEO audit, granted to various websites, does not authorize generalization. Sites that have obtained an identical or similar SEO audit result, depending on the scope of the tests and the rating scale, can be completely different.

By analyzing SEO attributes, one can create a technology profile and a specific site characteristic without browsing it first. Two factors determine the relevance of profiling: the auditor's experience and the quality and scope of the audit performed by the testing application. 


\section{References}

1. Ałaszkiewicz, A. (2015). Content marketing. In: I. Półog, M. Gałecki, M. Pawłowski, W. Wietecha (eds.), Poradnik dla internetowego reklamodawcy (pp. 33-39). IAB Polska. Retrieved from: https://goo.gl/WZGnbp, 14.04.2017.

2. Beitzel, S.M., Jensen, E.C., Chowdhury, A., Frieder, O., Grossman, D. (2007). Temporal Analysis of a Very Large Topically Categorized Web Query Log. Journal of the American Society for Information Science and Technology, 58(2), 166-178.

3. Bocchi, E., De Cicco, L., Rossi, D. (2016). Measuring the Quality of Experience of Web users. ACM SIGCOMM Computer Communication Review, 46(4), 8-13.

4. Chabior, B. (2017). Nie ma SEO bez dobrego contentu, czyli jak pisać pod Google'a. Raporty interaktywnie.com - Marketing w wyszukiwarkach, 33-40. Retrieved from: https://goo.gl/iG185p, 18.04.2018.

5. Duda, P. (2018). Pozycjonowanie i SEO - w czym jest różnica pojęć? Projekt Marketing. Retrieved from: https://goo.gl/3jo57A, 05.04.2018.

6. Dwornik, B. (2017). Kontent jest królem, a jakość królową. Raporty interaktywnie.comContent marketing, 42-48. Retrieved from: https://goo.gl/smHmRJ, 18.04.2018.

7. Gaczkowski, P. (2011). Świadomy wybór kluczem do sukcesu. Raporty interaktywnie.com - Marketing w wyszukiwarkach, 34-37. Retrieved from: https://goo.gl/iG185p, 17.04.2018.

8. Gałecki, M., Liegman, D., Połóg, I., Wietecha, W. (2016). Marketing w wyszukiwarkach. Raport z badania. IAB Polska. Retrieved from: https://goo.gl/T25hKd, 17.04.2018.

9. Grzybowska, K. (2017). Jak prowadzić skuteczna kampanię reklamowa $w$ wyszukiwarce?. Raporty interaktywnie.com - Marketing w wyszukiwarkach, 22-27. Retrieved from: https://goo.gl/3aJF9e, 18.04.2018.

10. Holliman, G., Rowley, J. (2014). Business to business digital content marketing: marketers' perceptions of best practice. Journal of Research in Interactive Marketing, 8(4), 269-293. http://dx.doi.org/10.1108/JRIM-02-2014-0013.

11. Konieczny, A., Szostak, M. (2011). Metodologiczne problemy profilowania kryminalnego. Problemy Kryminalistyki, 274, 26-35.

12. Król, K. (2015). Funkcjonalność oraz funkcje witryn internetowych gospodarstw agroturystycznych. Ekonomia i Zarzadzanie, 7(1), 343-355.

13. Król, K. (2017a). Konwersja celu w internetowej sprzedaży produktów turystyki wiejskiej. Problemy Drobnych Gospodarstw Rolnych - Problems of Small Agricultural Holdings, 2, 33-40.

14. Król, K. (2017b). Wybrane formy internetowych rekomendacji w promowaniu agroturystyki. Zagadnienia Doradztwa Rolniczego, 4(90), 27-39.

15. Król, K. (2018). Synergia kanałów marketingowych w internetowej promocji agroturystyki. Marketing i Rynek, 3, 32-36. 
16. Król, K., Zdonek, D. (2017a). Charakterystyka rynku usług hostingowych w Polsce. Zeszyty Naukowe Politechniki Śląkiej. Organizacja i Zarzadzanie, 102, 157-167. http://dx.doi.org/10.29119/1641-3466.2017.102.13.

17. Król, K., Zdonek, D. (2017b). Jakość witryn internetowych gospodarstw agroturystycznych małopolski według wybranych miar syntetycznych. Zeszyty Naukowe Politechniki Ślaskiej. Organizacja i Zarzadzanie, 102, 169-177. DOI: http://dx.doi.org/10.29119/16413466.2017.102.14.

18. Morville, P. (2005). Ambient Findability. Sebastopol, CA: O’Reilly Media.

19. Ocetkiewicz, R. (2017). Mobile napedza wzrosty w SEO i SEM. Raporty interaktywnie.com - Marketing w wyszukiwarkach, 8-13. https://goo.gl/3aJF9e, 14.04.2017.

20. Połóg, I., Gałecki, M., Pawłowski, M., Wietecha, W. (eds.) (2015). Poradnik dla internetowego reklamodawcy. IAB Polska. Retrieved from: https://goo.gl/WZGnbp, 14.04.2017.

21. Rempel, H.G., Bridges, L. (2013). That was then, this is now: Replacing the mobileoptimized site with responsive design. Information Technology and Libraries, 32(4), 8-24.

22. Słowik, S., Socha, P. (2016). Optymalizacja stron i sklepów internetowych. Część 2. Audyt SEO. Marketer+, 1(20), 98-101.

23. Smaga, M. (2011). Najczęstsze grzechy agencji pozycjonerskich. Raporty interaktywnie.com - Marketing $w$ wyszukiwarkach, 16-20, Retrieved from: https://goo.gl/iG185p, 17.04.2018.

24. StatCounter (2018). StatCounter GlobalStats. Search Engine Market Share in PolandMarch 2018, Retrieved from: https://goo.gl/AspXGR, 05.04.2018.

25. Suchy, Ł. (2017). Jak zatrzymać spadek ruchu i osiagnać wymarzone efekty w SEO case study apteka.pl. Raporty interaktywnie.com - Marketing $w$ wyszukiwarkach, 28-32. Retrieved from: https://goo.gl/3aJF9e, 14.04.2017.

26. Sztal, P. (2014). Algorytm Google'a - ranking parametrów SEO, czyli najpierw rzeczy najważniejsze. Online Marketing Polska, 4(17), 38-40.

27. Woźniak, M. (2015). Budowanie popularności serwisu działania off-site. In: I. Półog, M. Gałecki, M. Pawłowski, W. Wietecha (eds.), Poradnik dla internetowego reklamodawcy (pp. 26-32). IAB Polska. Retrieved from: https://goo.gl/WZGnbp, 14.04.2017.

28. Żytko, Ł. (2015). Optymalizacja serwisu internetowego działania on-site. In: I. Półog, M. Gałecki, M. Pawłowski, W. Wietecha (eds.), Poradnik dla internetowego reklamodawcy (pp. 17-25). IAB Polska. Retrieved from: https://goo.gl/WZGnbp, 14.04.2017. 